\title{
A Multidisciplinary Evaluation of Spatial Heterogeneity in the Puquios of the Salar de Llamara, Atacama Desert, Northern Chile
}

\section{R. Pamela Reid ( $\sim$ preid@rsmas.miami.edu )}

University of Miami

\section{Amanda Oehlert}

University of Miami

\section{Erica Suosaari}

Smithsonian Institution

\section{Cecilia Demergasso}

Catholic University of the North

\section{Guillermo Chong}

Catholic University of the North

\section{Lorena Escudero}

Catholic University of the North

\section{Alan Piggot}

Bahamas Marine EcoCentre

loan Lascu

Smithsonian Institution

\section{Alvaro Palma}

FisioAqua

\section{Research Article}

Keywords: Atacama Desert, high UV radiation, wide temperature variation, salt flats (salars)

Posted Date: February 1st, 2021

DOl: https://doi.org/10.21203/rs.3.rs-153999/v1

License: (c) (i) This work is licensed under a Creative Commons Attribution 4.0 International License. Read Full License 


\section{Abstract}

The Atacama Desert, Central Andes of Northern Chile, is an extreme environment characterized by high UV radiation, wide temperature variation, minimum precipitation and is reputed as the driest desert in the world. Scarce lagoons associated with salt flats (salars) in this desert are the surface expression of shallow groundwater which serve as refugia for life, and often host microbial communities associated with evaporitic mineral deposition. Recent investigations of the Puquios of the Salar de Llamara in the Atacama Desert based on multidisciplinary field studies provide unprecedented detail regarding the spatial heterogeneity of physical, chemical, and biological characteristics of such saline lake environments. Four main lagoons ('Puquios') and more than 400 smaller ponds, occur in an area less than $5 \mathrm{~km}^{2}$, are characterized by high variability in electrical conductivity, benthic and planktonic biota and microbiota, lagoon bottom type, and style of mineral deposition. The heterogeneity of system parameters as observed spatially in the Puquios is likely to be expanded with temporal observations incorporating seasonality. Results provide new insight into the complexity of these Andean ecosystems, which may be key to resilience in extreme environments at the edge of habitability.

\section{Introduction}

Life on Earth can thrive in almost every ecological niche, and many extremophiles prosper in the harshest of environments $^{1-6}$. Examples of extreme environments, where biologic communities persist at the edge of habitability, are common throughout some Andean ecosystems of South America ${ }^{3,7,8}$. Studies of more than 40 microbial ecosystems in Chile, Argentina, and Bolivia document a wide range of geological, chemical, biological and mineralogical processes occurring in these extreme environments ${ }^{8-22}$. Previous studies of these microbial ecosystems are predominantly focused on the deposition of carbonate minerals ${ }^{12-14,19,23}$, while the other studies have focused on the deposition of evaporitic minerals including gypsum, halite, and anhydrite, which dominate many of these systems ${ }^{15,18,19,24-30}$. One such example of a gypsum-depositing system is the series of lagoons locally known as Puquios, in the Salar de Llamara of the Atacama Desert. Recent studies of the Puquios suggest that multidisciplinary studies of the strong environmental gradients and a variety of microbial communities ${ }^{17,24,31,32}$, observed in this polyextreme environment will provide new insight into conditions that promote habitability at the dry limits of life.

The Salar de Llamara is located in one of the main endorheic basins in the Pampa del Tamarugal, Central Depression, of the Norte Grande de Chile ${ }^{33-35}$. The Puquios are variably sized depressions filled with ground brines. The Pampa del Tamarugal is the largest and last base level before the Pacific Ocean for the sedimentary fill and water input provided by the High and Preandean Cordilleras. The sedimentary fill corresponds to detrital sediments and volcanic rocks that can reach up to $1300 \mathrm{~m}$ thickness ${ }^{36}$. The Puquios in this arid to hyperarid environment of the Atacama Desert, are influenced by a complex interplay of physical, chemical, geological, and biological processes. Known environmental pressures include high fluxes of UV irradiation, extreme aridity, and significant fluctuations of temperature and 
salinity $27,37,38$ that contribute to the characterization as the dry limit of life ${ }^{39}$, of which the Puquios are a modern example. Despite these harsh environmental conditions, the Puquios support the development of a variety of pelagic and benthic communities, including microbial mats $17,19,24,29-31$, and exhibit diverse styles of gypsum deposition.

Previous studies in the Puquios have focused primarily on microscopy and molecular analyses of microbial communities in subaerial crusts and domes $15,18,20,24,27,29,30$ but detailed investigations of the relationship between physical, chemical, geological, ecological, and microbiological processes that may influence mineral deposition in these lagoons are limited. Initial studies in the Puquios of brines ${ }^{32,40}$ have begun to quantify stratification and lateral gradients of brine chemistry within a portion of the Puquios system in the Salar de Llamara. In this paper, we expand on this foundation by incorporating two additional areas within the Puquios system that have yet to be described. We incorporate a multidisciplinary approach to document the spatial heterogeneity of water chemistry, planktonic and benthic biota, community structure of the microbial ecosystems, lagoon bottom types, and mineral phases and morphologies in the Puquios. We base our observations on more than 1,285 in situ measurements of the brines, detailed ecological and chemical descriptions of each lagoon, as well as microbiological and morphological analysis of representative bottom types. The variability in spatial distributions observed throughout the system provide unprecedented insight into the complexity of this intriguing gypsum depositional ecosystem and highlight the need for spatial and temporal multi-disciplinary studies to understand ecosystem function and mineral deposition in these extreme environments. Results also lead to speculation that heterogeneity may be integral to the resilience of ecosystems that thrive at the edge of habitability.

\section{Environmental Setting}

The Puquios (Fig. 1) are located in the eastern part of the Salar de Llamara $\left(21^{\circ} 23^{\prime} \mathrm{S}-69^{\circ} 37^{\prime} \mathrm{W}\right)$, an actively depositing salar (salt flat) in the Pampa del Tamarugal, Central Depression ${ }^{24}$. This salar is located in the distal part of the Arcas Alluvial Fan that provides most of the basin input ${ }^{41}$. The hyperaridity of the Central Depression has fostered the deposition of evaporitic sediments since at least the Middle Miocene ${ }^{35}$, and is controlled by the geologic and oceanographic setting ${ }^{35,42-44}$. Rainfall is extremely low, estimated to be less than $1 \mathrm{~mm}$ in the Atacama Desert core ${ }^{45}$ as a result of the rainshadows cast by both the Coastal Cordillera and the High Cordillera. Furthermore, evaporation rates significantly exceed rainfall, with up to $90 \%$ of rainfall in the Western Cordillera lost via evaporation and runoff $^{46}$. The permanent surfacing of sub-terrain waters is recharged by a combination of summer monsoons (Invierno Altiplánico or Invierno Boliviano) in the High Cordillera ${ }^{47-49}$ that continuously drain through the alluvial fan systems punctuating the eastern margin of the basin ${ }^{35,50,51}$ with occurrences of coastal dripping fog 52,53 . The combination of these hydrological processes associated with the alluvial fan systems and the geomorphological characteristics at the boundary between the Coastal Cordillera and the Pampa del Tamarugal allows the shallow ground water levels to create the small lagoons called puquios with their biological communities. Brines in the Puquios are managed by SQM Ltd.; 
environmental protection measures were enacted in 2012 to preserve brine chemistry and water levels in the salar environment ${ }^{32,40,54,55}$.

The Puquios system is characterized by four main lagoons (Figs. 1b, 2), plus a series of smaller peripheral ponds (ranging from sub-meter to tens of meters in diameter). Puquio 1 consists of a main shallow lagoon with low-turbidity waters, an area of $1760 \mathrm{~m}^{2}$ and a maximum depth of $50 \mathrm{~cm}$. A multitude of small ponds exist between the main lagoons of Puquio 1 and 2 that are collectively referred to as "the Transition Zone". The Transition Zone contains nearly 400 small lagoons of various water turbidities, sizes, and depths (maximum depth recorded $80 \mathrm{~cm}$ ). Puquio 2 is largest lagoon in the Salar de Llamara with very low-turbidity brines, an area of $4650 \mathrm{~m}^{2}$ and a depth less than 1 meter. The main lagoon of the Puquio 3 system has an area of $1660 \mathrm{~m}^{2}$, elongated north - south, surrounded by a number of smaller, peripheral ponds. Water in Puquio 3 is clear, whereas the shallow peripheral ponds often have milky-white to peach-colored water. Puquio 4 consists of one main lagoon $\left(1485 \mathrm{~m}^{2}\right)$ elongated north south, surrounded by numerous peripheral ponds, mostly to the east. The main lagoon of Puquio 4 appears turquoise in color, and the water is clear, whereas the surrounding ponds also often have milkywhite to peach-colored water similar to those adjacent to Puquio 3.

\section{Results}

\section{Electrical Conductivity}

In the austral summer 2017-18, more than 1285 in situ measurements of electrical conductivity (EC, Fig. 2, Supplemental Table S1) were collected from both the surface brines and depths of the lagoons in the Puquios to characterize environmental gradients, and is interpreted to be a proxy for the salinity of the lagoon water. Chemical gradients on multiple scales were revealed; in situ measurements document spatial heterogeneity not only within the Puquios system as a whole, but also define a high degree of variability within a single lagoon.

Within the system as a whole, EC exhibited a high degree of spatial heterogeneity in the Puquios (Table 1, Supplemental Fig. S1, Supplemental Table S1). The lowest EC value was observed in the surface brine of a peripheral lagoon of Puquio $3(6.2 \mathrm{mS} / \mathrm{cm}$, Figs. 2c, 2d), and the highest EC values were observed in the surface brine of the main lagoon of Puquio 4 (164.9 mS/cm, Figs. 2e, 2f). Spatial trends in EC were also observed within the Puquios 1 and 2 system, where EC values grade from lower values in the main lagoon of Puquio 1 to significantly higher EC values in the main lagoon of Puquio 2 in the surface brine (Table 1, Figs. 2a, 2b). Observation of such variability in the Puquios system suggests that hydrological connections between each of the four Puquios may not be direct, and that higher EC values reflect higher degrees of evaporation and/or lower rates of groundwater flux into the brine pools.

Spatial heterogeneity was also found to be a significant characteristic of surface brines in the Puquios, even within a single lagoon. EC values within a single lagoon were found to vary through space, with ranges of more than $89.5,89.6$, and $138.0 \mathrm{mS} / \mathrm{cm}$ in the surface brines of the main lagoons in Puquios 2 , 
3 and 4 respectively (Figs. 2a, 2e). Comparison of surface brine EC measurements between the peripheral lagoons also demonstrated a large range in measured values across short distances, suggesting that the peripheral ponds can be isolated from the main lagoon water and may develop distinct EC values and degrees of spatial heterogeneity as a result. EC values of surface brines in the Transition Zone between Puquios 1 and 2 exhibit a range of more than $130.9 \mathrm{mS} / \mathrm{cm}$ (Fig. 2a).

Gradients in EC measurements were also a common characteristic of bottom brines in the Puquios. Like the surface brine measurements, the highest bottom brine EC value $(161.4 \mathrm{mS} / \mathrm{cm})$ was observed in Puquio 2, while the lowest EC measurement $(21.5 \mathrm{mS} / \mathrm{cm})$ was recorded in the bottom brines of Puquio 1 (Fig. 2b). Spatial heterogeneity of EC values in the bottom brines was reduced relative to the range observed in surface brines (Figs. 2a, 2b).

Differences between the measured EC values in the surface and bottom brines indicate that the pools were not only spatially heterogeneous, but also vertically stratified. Vertical stratification was defined following Babel (2004), where normal stratification is indicated by bottom values exceeding surface values, and inverse stratification is indicated by bottom values being lower than surface values. Results are presented in Table 1. Notably, stratification also exhibited spatial heterogeneity between lagoons: Puquios 1, 2, and 4 exhibited normal stratification, whereas measurements in Puquio 3 were nearly uniform, suggesting a well-mixed water column (Table 1) at the time of measurement.

\section{Free-Living Biota}

The free-living biota that thrives in the aquatic component of the Puquios system is comprised of four major groups, namely: phytobenthos (microalgae that exist on the bottom), phytoplankton (microalgae in the water column), zoobenthos (invertebrates found on the bottom or buried within the first few centimeters of substrate) and zooplankton (invertebrates in the water column). The first two groups, which are photosynthetic primary producers, are represented mainly by Diatoms ( 51 species) and by the less diverse Cyanobacteria (7 species). The primary and secondary consumers present on the bottom and in the water column are represented by 8 taxa: arachnids (spiders), annelids (worms), branchiopods (brine shrimps), coleopterans (beetles), copepods, dipterans (flies), hexapods (springtails), gastropods (snails) and odonates (dragonflies). Several of these taxa have complex life cycles and thus occur in different ontogenetic stages (i.e. from larval stages to adults). Some, like dipterans and odonates, only spend their larval phase in the water while some, like the brine shrimp Artemia franciscana, are holoplanktonic.

In the austral summer 2017-18, all four assemblages of biota exhibited ample variability in several ecological descriptors (e.g. number of taxa and Shannon diversity index), both within and between Puquios. The abundance of many species within each assemblage exhibited notable differences between Puquios (Fig. 3). The abundance of phytobenthos ranged from a few cells $/ \mathrm{mm}^{2}$ to ca. $700 \mathrm{cells} / \mathrm{mm}^{2}$ and was highest in Puquio 1, which also exhibited important differences among sampling points, followed by Puquio 2. Phytobenthos was least abundant in Puquios 3 and 4 (Fig. 3a). Phytoplankton exhibited an even more pronounced pattern of abundance variation between and within Puquios. The highest abundance of phytoplankton was recorded in the southern-most sampling point of Puquio 1 , 
more than twice of that found on its northern-most point. Puquios 2, 3 and 4 shared a uniform lower abundance in the range of 1,000 cells/L (Fig. $3 b$ ). The abundance of zoobenthos was also greater, and highly variable in Puquio 1 , with up to 90,000 individuals $/ \mathrm{m}^{2}$ in its northern section and around 20,000 individuals $/ \mathrm{m}^{2}$ along its southern edge. Puquio 2 , followed by 3 , displayed the lowest abundance, and Puquio 4 exhibited a varied and intermediate level of abundance (Fig. 3c). Zooplankton displayed a consistently low abundance in Puquios 1, 2 and 3, in contrast to Puquio 4, which was characterized by a relatively higher abundance of zooplankton, particularly in its southern-most section (Fig. 3d).

Besides abundance, other community-level descriptors, such as number of taxa (S) and Shannon diversity index $\left(\mathrm{H}^{\prime}\right)$, quantified for each of these four assemblages, varied amply (Table 2). Phytobenthos $S$ and $H^{\prime}$ values were as low as 13 and 0.11 , respectively in Puquio 4 and as high as 29 and 2.34, respectively in Puquio 3. The Phytoplankton diversity ranged from $S=7$ and $H^{\prime}=0.13$ in Puquio 4 to $S=36$ in Puquio 2 and $H^{\prime}=2.62$ in Puquio 3. The zoobenthos diversity ranged from $S=1$ and $H^{\prime}=0$ in Puquios 2 and 4 to $S=5$ and $H^{\prime}=1.29$ in Puquio 3 . The zooplankton diversity ranged from $S=2$ and $H^{\prime}=0.03$ in Puquio 4 to $S=6$ and $H^{\prime}=1.45$ in Puquio 1.

\section{Bacterial Community Analysis}

The microbial communities were assessed in March 2017 from subaerial gypsum structures (Fig. 4a) and brines. Bacterial community composition and predicted metabolisms reveal a heterogenous distribution of assemblages that is largely driven by local environmental factors. The microbial mat communities inhabiting the subaerial gypsum structures around the margins of the Puquios exhibit a stacking pattern at each sampling location, with a gradient of colors changing from green (E1) to brown (E2, E3) to colorless (E4) with increasing depth (Fig. 4b).

Samples of the E1 bacterial communities from twelve gypsum structures and four brines were analyzed by the $16 \mathrm{~S}$ rRNA gene bacterial amplicon sequencing. The bacterial diversity measured by $\mathrm{H}^{\prime}$ ranged from 2.5 to 5.8 in the E1 layer and 2.6-3.9 in the brines. The evenness index was less than 0.82 for the E1 layer and less than 0.61 for brine samples. The similarity between the E1 samples was $>40 \%$ at the phylum level and $>25 \%$ at the genus level. Bacteria in the E1 layer and brines affiliate mostly to high-rank prokaryotic taxa, Proteobacteria, Planctomycetes, Verrucomicrobia, Cyanobacteria, and Actinobacteria in important abundances. Within the Proteobacteria phylum, the alpha (orders Rhodobacterales, Rhizobiales) and gamma (orders Alteromonadales, Chromatiales) classes were predominant. The similarity among the brine samples was $>55 \%$ at the phylum and $>30 \%$ and the genus level. Bacteria in these groups affiliate mostly to the high-rank prokaryotic taxa Proteobacteria and Bacteroidetes as previously reported (Demergasso et al., 2007). Classes alpha (order Sphingomonadales) and gamma (orders Oceanospirillales and Vibrionales) were predominant within the Proteobacteria phylum.

The differences between the bacterial community profiles across the Puquios is driven largely by brine chemistry. The non-Metric Multi-dimensional scaling (nMDS) analysis grouped the Puquio 1 E1 samples separately from the other three Puquios, displaying a strong correlation to $\mathrm{EC}, \mathrm{pH}$, and $\mathrm{Mg}$ concentrations in the E1 layer (Pearson correlation > 0.8) (Fig. 4c). The grouping of the brine bacterial communities was 
also related to brine chemistry $\left(\mathrm{EC}, \mathrm{SO}_{4}{ }^{2-}\right.$ and $\mathrm{Mg}^{2+}$ ) (Pearson correlation $\left.>0.9\right)$, grouping Puquio 1 away from the other higher salinity locations (Fig. 4d). E1 samples from Puquio 1 contained higher abundances (Pearson correlation $>0.85$ ) of sulfate reducing bacteria (Desulfobacterales, Thermoanerobacterales) and some anoxygenic phototrophic and sulfur oxidizing Alphaproteobacteria (Rodobiaceae). Puquios 2, 3, and 4 were characterized by higher EC brine values and higher abundances of the halophilic and halotolerant genera of Cyanobacteria, Synechocystis, Halomicronema, Cyanotece and Euhalothece. The variability in the microbial communities of the brine samples was related to several genera of anoxygenic phototrophic bacteria from Alpha and Gammaproteobacteria and Chloroflexi groups.

The metabolisms from the predicted metagenomes by PICRUSt (Phylogenetic Investigation of Communities by Reconstruction of Unobserved States) suggests that there are not only key metabolic differences between E1 and brines, but also between E1 layers of structures related to the salinity characteristics at each sample location. The occurrence of the sulfur oxidation pathway appears to be dominant in both brines and subaerial structures (Fig. 4e). Phototrophy is more abundant in E1 samples, whereas heterotrophic and aerobic metabolisms are more important in the brine samples (Fig. 4e). There is also a clear differentiation between the subaerial structures. Anoxygenic and oxygenic photosynthesis are more abundant in E1 from the most saline ponds. Meanwhile, nitrate and sulfate reduction and the use of $\mathrm{CO}$ and $\mathrm{H}_{2}$ as electron donors are more represented in E1 from the lowest saline pond.

Desulfobacterales was observed among the sulfate reducers which has been reported previously in the subaqueous structures ${ }^{29}$. Desulfobacterales was registered as a dominant, active SRB and primary hydrogenotrophs in the upper layer of a microbial mat ${ }^{56}$.

\section{Bottom types and mineral precipitation}

In the austral summer 2017-18, a range of different bottom types (Fig. 5) and corresponding variations in mineral precipitation (Fig. 6) were observed within the Puquios, as summarized below.

The bottom of Puquio 1 was dominated by loose flocculant sediment (Supplementary Fig. S2k), lacking lithified mineral structures with topographic relief. Scanning Electron Microscopy / Energy Dispersive XRay Spectroscopy (SEM/EDS) analyses documented abundant small granular crystals of gypsum within the flocculent material, often forming aggregations. Carbonates and magnesium clays were also present. Microbes and exopolymeric substance (EPS) were intimately associated with the minerals in Puquio 1, suggesting microbial influence on mineral precipitation in this lagoon (Table 3 ).

Bottom types in the Transition Zone were highly variable, grading from flocculent sediment to a variety of orange, brown, and black microbial mats, with various morphologies. SEM analyses of critically dried samples of mat types throughout the Transition Zone (Figs. 6a-6h) showed intimate mixtures of EPS, microbes and diatoms with fine-grained minerals (primarily gypsum), often with distinct lamination of the mineral substrate. Gypsum crystals within the microbial mats exhibited various habits including bipyramidal, acicular, platy, lenticular, etc., and small crystals often aggregated into larger crystals within organic matrices (Figs. 6c, 6d, 6g). Accumulations of minerals and microbes were present in most 
samples examined. Another striking characteristic of samples collected from ponds in the transitional zone was the common appearance of small acicular crystals accruing along filamentous cyanobacterial sheaths (Fig. 6h). Additional mineral accumulations found in abundance throughout the Transition Zone included various carbonate species, sodium sulfates, magnesium clays, and manganese oxides. As in Puquio 1, mineral deposition in the Transition Zone was largely microbially influenced (Table 3).

In the Transition Zone to the southwest of Puquio 2 and within Puquio 2 the bottom type was characterized by euhedral gypsum spar (Supplementary Figs. S2aa, S2ab, Fig. 6a). Samples displayed $\mathrm{cm}$-scale selenite crystals and lacked organic matrices. These large crystals had well-developed crystal faces and were sometimes coated with manganese oxides (Fig. $6 \mathrm{~m}$ ). The bottom of Puquio 2 was blanketed by gypsum spar crystals and lacked dense bacterial communities. The side walls of Puquio 2 were comprised mainly of gypsum botryoids, which often merged into plates. Diatoms were prevalent, often in great abundance. The large crystals, lack of agglutinated grains, and paucity of observed microbes and EPS suggests that microbial influence was limited, and mineral precipitation was largely physiochemical (Table 3).

The main lagoon of Puquio 3 was dominated by pinnacles (Fig. 5c, Supplemental Figs. S2v, S2w, and S3c) along the northwestern margin of Puquio 3, and orange/brown microbial mats in the southeast (Fig. 5c, Supplemental Figs. S2t, S3c). SEM/EDS analyses revealed granular and laminated gypsum accumulations closely associated with microbes (Supplemental Table S2, Figs. 6q-6t). A sample collected in the south exhibited larger crystals and aggregates, whereas a sample collected in the north of Puquio 3 (Fig. 6r) was largely microcrystalline. Mineral precipitation appears both microbially and physicochemically mediated (Table 3 ).

The dominant bottom type in Puquio 4 was gypsum spar (Fig. 5e, Figs. 6q-6t, Supplemental Fig. S2y, Supplemental Fig. S3e). Where water circulation was poor around the margins, floccules were common (Fig. 5f, Supplemental Figs. S2k, S3f). A single sample collected from the northeast margin of Puquio 4 (Figs. 6u-6x, Supplemental Table S2) was a well-cemented aggregate of coarse (>100 $\mu \mathrm{m})$ crystals of gypsum. Although not abundant in the sample, microbes and EPS were also present. Mineral precipitation appears to be driven by physicochemical processes (Table 3).

\section{Discussion}

Results above allow us to characterize the Puquios in terms of heterogeneity. Heterogeneity in turn may foster ecosystem resilience, enabling habitability within the polyextreme conditions that characterize the hyper arid environment of the Atacama Desert (sensu ${ }^{57}$ ).

Heterogeneity of biota, microbial communities, lagoon bottom types and type of mineral precipitation within the Puquios as documented above, appears to be driven by spatial variability in brine chemistry. Variations in water level and brine chemistry may drive changes in microbial communities as their abundances and functions respond to changing environmental conditions through time. Functional 
redundancy in the system is hypothesized to contribute to a high degree of resilience in response to changes in brine chemistry and lifestyle allowing these microbial communities to persist in harsh polyextreme conditions. Where EC is relatively low, as in Puquio 1 and the Transition Zone, microbial mats are common (Supplemental Fig. S4a - S4c) and the microscopic analysis revealed a heterogeneous distribution of filamentous and unicellular cyanobacteria, cell morphologies compatible with chromatium and diatoms (Supplemental Fig. S5). Abundances of phytobenthos and zoobenthos are relatively high, and mineral deposition, primarily gypsum, is largely microbially driven. In contrast, when brines have high EC values, such as those observed in Puquio 2 (Fig. 2c, F, Supplemental Fig. S1) the occurrence of microbial mats is rare and the bottom is covered by gypsum crystals, water column biota are present in lower proportions, and gypsum precipitation appears to be largely physicochemical (Supplemental Fig. S4d). Although more work is needed to delineate physicochemical versus microbial controls on gypsum precipitation, mineral precipitation in Puquio 3 appears influenced by both microbial and physicochemical controls, whereas Puquio 4 appears dominated by physicochemical controls. In both sites microbial mats are covered by different gypsum morphologies (Supplemental Fig. S4e, S4f, respectively).

Heterogeneity observed in all studied aspects of the Puquios is hypothesized to generate a system that contains diverse ecological niches within the brines, porewaters, subaerial structures, and microbial mats that characterize this system. Furthermore, seasonal changes in brine chemistry and water level in the system, are likely to impact all of the ecological niches to varying degrees. Dynamic interplay between physical, chemical, geological and biological processes is thought to generate unique communities that foster different styles of life, including both the community structure and function. For example, the Invierno Altiplanico that occurred in January - February 2017 is hypothesized to have impacted both water levels and microbial communities in Puquio 1. Higher water levels after the Invierno Altiplanico likely filled the pore spaces of the subaerially exposed structures, reduced available oxygen in the environment that fosters endoevaporitic microbial communities, and produced the observed enrichment in the anaerobic microbial population in Puquio 1 samples during the March 2017 field campaign. The surface water level therefore is an important determinant of the shift from a subaerial to a subaqueous lifestyle as was previously observed ${ }^{58}$. Considering that EC has an indirect correlation with surface water level in the Puquios $\left(R^{2}=0.50\right.$ to 0.83$)$, seasonally variable water levels in Puquio 1 may drive the relationship between EC and microbial community structure in Puquio 1, distinguishing it from similar endoevaporitic communities near Puquios 2, 3 and 4. Similar seasonal differences in Anaerobic Deltaproteobacteria abundances were observed between summer and winter samples in a previous study ${ }^{17}$ and between the depths analyzed in subaqueous niches in March $2012^{29}$.

Gradients in environmental parameters have previously been described in the Puquios $32,59,60$, as well as in a variety of Andean microbial ecosystems, such as Lake Tebenquiche in Chile ${ }^{25}$, Lake La Brava in Chile, and Lake Socompa in Argentina 19,23,27. These environmental settings are associated with biological communities that are tolerant to extreme conditions ${ }^{17}$, including a reduced group of invertebrates, such as brine shrimps, insects and other planktonic organisms, as well as macrophytes 
adjacent to the ponds ${ }^{61-65}$. Phototrophs in the desert lagoons are mainly represented by diatoms and cyanobacteria $25,66,67$, with broad representation of phototrophic microbial communities ${ }^{68}$. Diatoms have been well-studied as a result of their abundance in all Northern Chile aquatic systems. Species in both groups function as indicators of water chemistry characteristics ${ }^{65}$.

Beyond Andean microbial ecosystems, extreme environments have been observed in other modern and ancient hypersaline lagoons, lakes in arid settings, sabkha environments, and anthropogenically-driven evaporite depositional settings, such as the salt works at Guerrero Negro ${ }^{69-71}$ and the EMISAL salt works in Egypt ${ }^{72,73}$. Such extreme conditions typically subject resident biota to wide fluctuations in temperature, salinity, $\mathrm{pH}$, dissolved oxygen, total dissolved solids and redox potential ${ }^{74,75}$. In these environments, high light intensity is often coupled with low-redox potential and low oxygen concentration; heavy metals and nutrients may also fluctuate ( $\left.\mathrm{sensu}^{76}\right)$. As such, observations of horizontal and vertical heterogeneity in brine chemistry, in particular electrical conductivity, and the corresponding diversity of the biological and mineralogical components of the Puquios appear to be characteristic of extreme environments. Similarly, shallow lagoons within these settings may be subject to long periods of desiccation during seasonal changes. Moreover, seasonal and interannual variability in climate, aridity, water activity, UV, and temperature will likely produce even more dramatic environmental gradients than those observed during the November 2017 field campaign.

Furthermore, ecosystem heterogeneity is an important driver of biodiversity and ecosystem resilience (e.g. 77-81), that would enable habitability within the polyextreme environmental conditions of the Puquios. Heterogeneity fosters resilience to environmental change as a result of multiple factors at various levels of biological organization ${ }^{79}$. At the landscape level, spatial heterogeneity affects localized responses to perturbations ${ }^{82}$, providing a greater range of resources and microenvironments that can act as buffers to inhabitants ${ }^{78,83-85}$. In the Puquios, spatial heterogeneity of brine chemistry is a dominant driver of microbial diversity and the dominant metabolic pathways between brine communities and E1 layer of the subaerial structures. Most notable was the diversity within the E1 layer communities given they reside above the brines and are largely phototrophic, yet they are impacted by the surrounding brines. The strong brine chemical gradient across the Puquio system provides juxtaposed habitats that can provide nutrients and resources to support heterotrophically dominated aqueous communities as well as halotolerant communities on the extreme end, and autotrophic communities in the subaerial structures. The overall diversity appears to be created by a geochemical architecture where mineral precipitation creates multiple niches where metabolically flexible communities can persist in a polyextreme environment. Indeed, studies have shown that community diversity increases the capacity of biota to survive and/or recover from perturbations (e.g. $\left.{ }^{86-88}\right)$.

Spatial heterogeneity coupled with complexity promotes species coexistence by providing a wide range of niche environments, which can enhance species diversity ${ }^{89}$. Spatially variable brine chemistry in the Puquios was shown to generate a diversity of biological communities in both planktic and benthic communities of eukaryotes and prokaryotes, a gradient in the role of biological influence on mineral 
deposition, and a variety of mineral assemblages. These intra- and interspecific variations allow redundancy, combined functioning and interaction of species, as well as differing responses, tolerances, and adaptability $\left(\operatorname{sensu}^{79}\right)$, which is critical for the ecosystem to thrive in response to environmental perturbations, leading to resilience at multiple scales.

On the scale of microns to hundreds of meters, these multi-disciplinary observations of the Puquios provide a case study of the inherent heterogeneity unique to these extreme environments. We argue that the importance of variability observed in the Puquios at multiple scales can likely be extended to encompass the wider complex of Andean microbial ecosystems in all of northern Chile, Argentina, and Bolivia $^{8}$. Spanning several orders of magnitude, this spatial heterogeneity of physical, chemical, biological and geological processes observed is hypothesized to be the cornerstone for the resilience of these ecosystems that persist in some of the harshest conditions on Earth.

\section{Conclusions}

The Puquios are a highly diverse ecosystem, and just one example of the high degree of heterogeneity across multiple scales of observation within Andean polyextreme environments that host microbial ecosystems. Each lagoon has distinct spatial trends in electrical conductivity, biological diversity of water column and benthic primary producers and consumers, heterogeneous microbial communities, and a variety of sedimentary structures and textures and mineral phases. While primary producers like phytoplankton and phytobenthos thrive at comparable high diversities throughout the Puquios, their total abundance is greater in the Puquio with the lowest EC. On the other hand, consumers (zooplankton and zoobenthos) exhibit lower diversity throughout, mainly represented by few very specialized taxa (e.g. Artemia franciscana), with varied abundance patterns that do not necessarily relate to EC ranges. Microbial communities in the Puquios also exhibit spatially complex trends that appear to be related to a variety of ecological niches (brines, subaerial structures, submerged microbial mats). Differences in lifestyle are likely produced by the niche's inherent biogeochemical response to environmental change, leading to the observed diversity, function, and structure of the microbial communities that inhabit them. The ability of a community to shift between lifestyles, as observed in the endoevaporitic communities near the margins of the Puquios, should be considered a source of diversity and resilience. However, for a better understanding of the communities' response to typical environmental changes experienced on a seasonal time scale (sensu ${ }^{32,54,55}$ ), a multi-disciplinary surveying effort across broader spatio-temporal scales is needed. Bottom types and coupled mineral precipitation revealed a wide depositional spectrum ranging from fine-grained granular gypsum precipitation with microbial influences to large sparry accumulations of selenite with little or no microbial influences. Moreover, it is likely that these biological, physical, chemical, and geological observations from a single point in time do not capture the full range of heterogeneity through time and at multiple scales. Seasonal changes in precipitation, evaporation, temperature, and climatic conditions drive temporal variability at least as extreme as the spatial heterogeneity documented in this study $32,54,55$. Initial characterization of heterogeneity across multiple scales and disciplines at a single point in time provides important baseline data to allow comparisons 
with other active systems and to better understand relationships between heterogeneity and resilience, including the capacity of an ecological community to reorganize after disturbances. Documenting the heterogeneity of the Puquio ecosystem across multiple disciplines provides unprecedented insight into the complexity of an ecosystem at the edge of habitability.

\section{Methods}

\section{Quantification of benthic and pelagic biota}

Biotic survey of water column and benthic organisms was performed at 5 sites within each of the 4 Puquios. At each site 3 replicate samples were obtained. For zooplankton and phytoplankton $36 \mathrm{~L}$ of water was passed through a $35 \mu \mathrm{m}$ and $60 \mu \mathrm{m}$ sieve respectively by means of an electrical immersion pump powered by a portable $12 \mathrm{~V}$ battery. Each sample was summarized and introduced into a $50 \mathrm{~mL}$ Falcon tube and fixed using $2 \%$ Lugol for phytoplankton and $5 \%$ diluted formalin for zooplankton. For phytobenthos, an $875 \mathrm{~mm}^{2}$ cylindrical plexiglass tube was gently introduced into the top bottom $1 \mathrm{~cm}$ layer of the substrate and all material collected stored into a $15 \mathrm{~mL}$ Falcon tube and fixed using $2 \%$ Lugol. Zoobenthos samples were collected using a $1,256 \mathrm{~mm}^{2}$ cylindrical plexiglass tube that was also introduced into the top 1-2 cm layer of substrate and all collected material stored into an $80 \mathrm{ml}$ plastic container and fixed with $5 \%$ diluted formalin. Phytoplankton and phytobenthos quantification analyses considered APHA (2012) methods 10200 C, D, E, F and 10300 C, and for identification several sources were consulted (e.g. ${ }^{66,87,90-97}$ ). Zooplankton and zoobenthos quantification analyses considered APHA (2012) methods $10200 \mathrm{G}$ and $10500 \mathrm{~A}, \mathrm{C}$ and Woelf et al. ${ }^{98}$ and for identification several specialized sources were consulted (e.g. $\left.{ }^{63,99-103}\right)$.

\section{Characterization of Microbial Communities}

Bacterial communities were collected from subaerial gypsum structures at 3 sites from each of the four Puquios $(n=12)$ using a $20 \mathrm{~cm}$ sediment core device. A sample of the microbial mat inhabiting the gypsum structure was collected from the E1 'green layer'. A $1 \mathrm{~L}$ brine sample was collected from the water surrounding each subaerial gypsum structure for comparison between the planktonic microbial community and the microbial mat community. The E1 from each core sample of the subaerial gypsum structures was isolated in the lab for DNA extraction and the brines were filtered by a nitrocellulose membrane with a $0.22 \mu \mathrm{m}$ pore size (Merck-Millipore, Germany) to collect the cells as it was reported before $^{104}$. The filter was then folded and placed in a tube with a hypertonic lysis buffer solution $(25.7 \%$ sucrose, $50 \mathrm{mM}$ TRIS- $\mathrm{HCl}, 40 \mathrm{mM}$ EDTA) and was kept at $-20^{\circ} \mathrm{C}$ up to later processing. DNA was obtained using the AllPrep Qiagen RNA/DNA Isolation Kit (Qiagen, USA). The extraction yield and DNA purity were determined by means of gel electrophoresis and UV-Visible spectrophotometry (Nanodrop, Thermo, Germany).

The V1-V3 variable region of the 16S rRNA gene were amplified in a PCR thermocycler using the primers $27 f$ (5'-AGAGTTTGATCCTGGCTCAG-3') ${ }^{105}$ and 534r (5'-ATTACCGCGGCTGCTGG-3') ${ }^{22}$ for bacteria with a 
barcode on the forward primer. PCR was performed using the HotStarTaq Plus Master Mix Kit (Qiagen, USA) under the following conditions: $94^{\circ} \mathrm{C}$ for 3 minutes, followed by 28 cycles of $94^{\circ} \mathrm{C}$ for 30 seconds, $53^{\circ} \mathrm{C}$ for 40 seconds and $72^{\circ} \mathrm{C}$ for 1 minute, after which we performed a final elongation step at $72^{\circ} \mathrm{C}$ for 5 minutes. PCR products were visualized in $2 \%$ agarose gel to determine the success of amplification and the relative intensity of the bands. Multiple equivalent samples of PCR products were pooled together in equal proportions based on their molecular weight and DNA concentrations. Pooled samples were purified using calibrated Ampure XP beadsto prepare a DNA library by following the Illumina TruSeq DNA library preparation protocol. Sequencing was performed at MR DNA (www.mrdnalab.com, Shallowater, TX, USA) on a MiSeq, following the manufacturer's guidelines. The sequence data were processed using a proprietary analysis pipeline (MR DNA) with the following steps: the barcodes were eliminated from sequences, then sequences $<150 \mathrm{bp}$ and those with ambiguous base calls were removed. Then, sequences were denoised, OTUs generated and chimeras removed. The reads were added to the Sequence Read Archive (SRA) National Center for Biotechnology Information (NCBI), (http://trace.ncbi.nlm.nih.gov/Traces/sra/). Project numbers - BioProject accession: PRJNA659028 (Puquios of the Salar de Llamara Raw sequence read); BioSample: SAMN15924840 (A multidisciplinary evaluation of spatial heterogeneity in the Puquios of the Salar de Llamara, Atacama Desert, Northern Chile); SRA: SRR12536357 (Puquios of the Salar de Llamara Atacama Desert).

The sequences were processed further by means of the QIIME (Quantitative Insights Into Microbial Ecology) pipeline ${ }^{106}$ : Raw sequences were filtered by base quality score, average base content per read and GC distribution in the reads. Reads that did not cluster with other sequences, i.e. singletons (abundance < 2) were removed. Chimeras were also removed using the UCHIME program ${ }^{107}$. The preprocessed sequences were finally grouped into operational taxonomic units (OTUs) using the clustering program UCLUST at a similarity threshold of $0.97^{107}$. The pre-processed reads were used to identify the OTUs using QIIME and aligned the representative sequences against the Greengenes core set reference database using PyNAST ${ }^{106}$. A representative sequence for each OTU was classified using RDP classifier and the Greengenes OTU database. The alpha-rarefaction was then calculated by means of the "core_diversity_analysis" command and standardized the number of sequences to the smaller sample size by means of Chao 1 (2599 sequences). The rarefacted data using the Primer-7 (Primer-E) software ${ }^{108}$ was used to determine the beta diversity and plot the main coordinates graphs.

\section{In Situ Electrical Conductivity Measurements}

In situ measurements of electrical conductivity (EC) were collected over the course of three days in November 2017 using a HI 9829 multimeter (Hanna Instruments, Rhode Island, USA). The EC probe was calibrated to known standards of EC values (HI7031L and HI7035, Hanna Instruments, Rhode Island USA) each morning before the start of field sampling. Sample locations were collected with a Garmin GPSMap 78s. For EC, the manufacturer specifications for accuracy is $\pm 1 \mu \mathrm{S} / \mathrm{cm}$ or $\pm 1 \%$ of the reading, whichever is larger. Measurement resolution is $1 \mu \mathrm{S} / \mathrm{cm}$, and the range is $0-200 \mathrm{mS} / \mathrm{cm}$. At each location, both a surface measurement and bottom brine measurement were collected. Surface measurements were collected first at about $5 \mathrm{~cm}$ depth in order to minimize disruption of any brine stratification, with the 
probe oriented parallel to the water surface. Bottom brines were measured second by slowly lowering the probe to the bottom of the lagoon and laying it horizontally. Bottom measurement collection was delayed until EC values stabilized, often 15-20 seconds. These field measurements, brine depths, and GPS locations were merged into a spreadsheet and their spatial distributions mapped in ArcGIS Pro. The data were evaluated by calculating the average and standard deviations, as well as calculating the interquartile range (IQR) using the exclusive quartile calculation in Microsoft Excel (Office 365). Stratification was calculated following the methods of Babel (2004), where surface measurements are subtracted from bottom measurements. Normal stratification is then defined as bottom measurements being greater than surface measurements, and inverse stratifications are defined as bottom measurements being lower than surface measurements.

\section{Bottom type mapping and microbe-mineral interactions}

To distinguish physio-chemical substrates in the Puquios from substrates that are products of benthic organisms, we adopted a multiscale approach. At the macroscale, broad facies patterns were mapped using aerial imagery; these bottom type maps were refined using comprehensive ground truthing. This mapping approach identified principal bottom types based on upper few centimeters of the substrate surface across the Puquios system (Supplementary Fig. S2 and S3). At the mesoscale, hand samples of the different bottom types were described (Supplemental Table S2). At the microscale, crystal morphologies in context with surrounding matrices were analyzed in the lab using scanning electron microscopy (SEM) with electron dispersive spectroscopy (EDS). This comprehensive approach defined mapping units used to document spatial distribution of bottom types and distinguished between abiotic mineral structures and those mineral deposits influenced and/or induced by microbial mats.

High resolution drone images of the Puquios, collected in November 2017, were loaded onto an iPad mini into Global Mapper Mapper Mobile, a powerful GIS data viewing and field data collection application for iOS. The software application uses the iPad's GPS capability to provide location information for remote mapping projects. The iPad mini was used in the field during the January 2018 field campaign where drone imagery and shapefiles were loaded into the application and subsequently, multiple locations throughout and around each Puquio, including all accessory ponds were investigated. At each location, a photograph was taken, and the bottom type was identified and described.

SEM imaging was performed on a ThermoFisher Scientific Apreo Field Emission Scanning Electron Microscope fitted with a compound electrostatic and immersion final lens, low vacuum capability and Edax Octane Energy Dispersive X-Ray Spectrometer (EDS) with $60 \mathrm{~mm}$ Silicon Drift Detector at Smithsonian National Museum of Natural History.

\section{Declarations}

\section{Acknowledgements}


The authors are grateful to René Daza, Sara Swaminathan, Blake Cunningham, Nicolas Barroilhet, Kevin Coloma, and Andy White for their help in field sampling and data organization. SQM Ltd is acknowledged for funding this study and providing logistical support in the field.

\section{References}

1. Rothschild, L. \& Mancinelli, R. Life in extreme environments. Nature 409, 1092-1101 (2001).

2. Cavicchioli, R. Extremophiles and the Search for Extraterrestrial Life. Astrobiology 2, 281-292 (2002).

3. Parro, V. et al. A Microbial Oasis in the Hypersaline Atacama Subsurface Discovered by a Life Detector Chip: Implications for the Search for Life on Mars. Astrobiology 11, 969-996 (2011).

4. Lee, C. J. D. et al. NaCl-saturated brines are thermodynamically moderate, rather than extreme, microbial habitats. FEMS Microbiol. Rev. 42, 672-693 (2018).

5. Coleine, C. et al. Specific adaptations are selected in opposite sun exposed Antarctic cryptoendolithic communities as revealed by untargeted metabolomics. PLoS One 15, 1-17 (2020).

6. Rathour, R. et al. A comparative metagenomic study reveals microbial diversity and their role in the biogeochemical cycling of Pangong lake. Sci. Total Environ. 731, 139074 (2020).

7. Finstad, K. M. et al. Microbial Community Structure and the Persistence of Cyanobacterial Populations in Salt Crusts of the Hyperarid Atacama Desert from Genome-Resolved Metagenomics. Front. Microbiol. 8, 1435 (2017).

8. Farías, M. E. \& Saona Acuña, L. A. Modern Microbial Mats and Endoevaporite Systems in Andean Lakes: A General Approach. in Microbial Ecosystems in Central Andes Extreme Environments (ed. Farías, M. E.) 21-33 (Springer, Cham, 2020). doi:https://doi.org/10.1007/978-3-030-36192-1_2

9. Demergasso, C. et al. Microbial mats from the Llamara salt flat, northern Chile. Rev. Chil. Hist. Nat. 76, 485-499 (2003).

10. Farías, M. E., Villafañe, P. G. \& Lencina, A. I. Integral Propsection of Andean Microbial Ecosystem Project. in Microbial Ecosystems in Central Andes Extreme Environments (ed. Farías, M. E.) 245-260 (Springer, Cham, 2020). doi:https://doi.org/10.1007/978-3-030-36192-1_17

11. del Rocío Mora-Ruiz, M. \& Díaz-Gil, C. Microbial Diversity in Athalassohaline Argentinean Salterns. in Microbial Ecosystems in Central Andes Extreme Environments (ed. Farías, M. E.) 165-179 (Springer, Cham, 2020). doi:https://doi.org/10.1007/978-3-030-36192-1_12

12. Boidi, F. J., Mlewski, E. C., Gomez, F. J. \& Gérard, E. Characterization of Microbialites and Microbial Mats of the Laguna Negra Hypersaline Lake (Puna of Catamarca, Argentina). in Microbial Ecosystems in Central Andes Extreme Environments (ed. Farías, M. E.) 183-203 (Springer, Cham, 2020). doi:https://doi.org/10.1007/978-3-030-36192-1_13

13. Albarracín, V. H., Galván, F. S. \& Farías, M. E. Extreme Microbiology at Laguna Socompa: A HighAltitude Andean Lake (3570 m a.s.I.) in Salta, Argentina. in Microbial Ecosystems in Central Andes Extreme Environments: Biofilms, Microbial Mats, Microbialites and Endoevaporites (ed. Farías, M. E.) 205-220 (Springer International Publishing, 2020). doi:10.1007/978-3-030-36192-1_14 
14. Gomez, F. J., Boidi, F. J., Mlewski, E. C. \& Gérard, E. The Carbonate System in Hypersaline Lakes: The Case of Laguna Negra (in the Puna Region of Catamarca, Argentina). in Microbial Ecosystems in Central Andes Extreme Environments 231-242 (Springer, Cham, 2020).

doi:https://doi.org/10.1007/978-3-030-36192-1_16

15. Demergasso, C. et al. Distribution of prokaryotic genetic diversity in athalassohaline lakes of the Atacama Desert, Northern Chile. FEMS Mirobiology Ecol. 48, 57-69 (2004).

16. Escudero, L. et al. A thiotrophic microbial community in an acidic brine lake in Northern Chile. Antonie Van Leeuwenhoek 111, 1403-1419 (2018).

17. Rasuk, M. C. et al. Microbial Characterization of Microbial Ecosystems Associated to Evaporites Domes of Gypsum in Salar de Llamara in Atacama Desert. Microb. Ecol. 68, 483-494 (2014).

18. Rasuk, M. C. et al. Bacterial Diversity in Microbial Mats and Sediments from the Atacama Desert. Microb. Ecol. 71, 44-56 (2016).

19. Rasuk, M. C., Visscher, P. T., Leiva, M. C. \& Farías, M. E. Mats and Microbialites from Laguna La Brava. in Microbial Ecosystems in Central Andes Extreme Environments (ed. Farías, M. E.) 221-230 (Springer, Cham, 2020). doi:978-3-030-36192-1

20. Rasuk, M. C., Leiva, M. C., Kurth, D. \& Farías, M. E. Complete Characterization of Stratified Ecosystems of the Salar de Llamara (Atacama Desert). in Microbial Ecosystems in Central Andes Extreme Environments (ed. Farías, M. E.) 153-164 (Springer, Cham, 2020). doi:https://doi.org/10.1007/978-3-030-36192-1_11

21. Shen, J., Zerkle, A. L., Stueeken, E. \& Claire, M. W. Nitrates as a Potential N Supply for Microbial Ecosystems in a Hyperarid Mars Analog System. Life 9, (2019).

22. Aszalós, J. M. et al. Bacterial Diversity of a High-Altitude Permafrost Thaw Pond Located on Ojos del Salado (Dry Andes, Altiplano-Atacama Region). Astrobiology 20, 754-765 (2020).

23. Farias, M. E. Prokaryotic diversity and biogeochemical characteristics of benthic microbial ecosystems at La Brava, a hypersaline lake at Salar de Atacama , Chile. (2017).

24. Demergasso, C. et al. Microbial mats from the Llamará salt flat, northern Chile. Rev. Chil. Hist. Nat. 76, 485-499 (2003).

25. Demergasso, C. et al. Novelty and spatio-temporal heterogeneity in the bacterial diversity of hypersaline Lake Tebenquiche (Salar de Atacama). Extremophiles 12, 491- 504 (2008).

26. Stivaletta, N., Barbieri, R., Cevenini, F. \& López-García, P. Physicochemical conditions and microbial diversity associated with the evaporite deposits in the Laguna de la Piedra (Salar de Atacama, Chile). Geomicrobiol. J. 28, 83-95 (2011).

27. Farías, M. E. et al. Characterization of bacterial diversity associated with microbial mats, gypsum evaporites and carbonate microbialites in thalassic wetlands: Tebenquiche and La Brava, Salar de Atacama, Chile. Extremophiles 18, 311-329 (2014).

28. Fernandez, A. B. et al. Microbial diversity in sediment ecosystems (evaporites domes, microbial mats, and crusts) of Hypersaline Laguna Tebenquiche, Salar de Atacama, Chile. Front. Microbiol. 7, 1-18 (2016). 
29. Saghaï, A. et al. Unveiling microbial interactions in stratified mat communities from a warm saline shallow pond. Environ. Microbiol. 19, 2405-2421 (2017).

30. Gutiérrez-Preciado, A. et al. Functional shifts in microbial mats recapitulate early Earth metabolic transitions. Nat. Ecol. Evol. 2, 1700-1708 (2018).

31. Demergasso, C. et al. Distribution of prokaryotic genetic diversity in athalassohaline lakes of the Atacama Desert, Northern Chile. FEMS Microbiol. Ecol. 48, 57-69 (2004).

32. Otálora, F. et al. Hydrochemical and Mineralogical Evolution through Evaporitic Processes in Salar de Llamara Brines (Atacama, Chile). ACS Earth Sp. Chem. 4, 882-896 (2020).

33. Chong-Díaz, G. Die Salare in Nordchile - Geologie, Struktur und Geochemie. Geotektonische Forschungen (1984).

34. Risacher, F. \& Fritz, B. Geochemistry of Bolivian salars, Lipez, southern Altiplano: Origin of solutes and brine evolution. Geochim. Cosmochim. Acta 55, 687-705 (1991).

35. Pueyo, J. J., Chong, G. \& Jensen, A. Neogene evaporites in desert volcanic environments: Atacama Desert, northern Chile. Sedimentology 48, 1411-1431 (2001).

36. Simicic Hernández, Y. P. Thickness distribution of the oligo-neogenous sedimentary cover of the Tamarugal pampas, northern Chile $\left(20^{\circ} 45^{\prime}\right.$ to $\left.21^{\circ} 30^{\prime} \mathrm{S}\right)$. (Universidad de Chile, 2015).

37. Cabrera, S., Bozzo, S. \& Fuenzalida, H. Variations in UV radiation in Chile. J. Photochem. Photobiol. B Biol. 28, 137-142 (1995).

38. Cabrol, N. A. et al. Life in the Atacama: Searching for life with rovers (science overview). J. Geophys. Res. Biogeosciences 112, (2007).

39. Navarro-González, R. et al. Mars-Like Soils in the Atacama Desert, Chile, and the Dry Limit of Microbial Life. Science (80- ). 302, 1018-1021 (2003).

40. Surma, J., Assonov, S., Herwartz, D., Voigt, C. \& Staubwasser, M. The evolution of 170-excess in surface water of the arid environment during recharge and evaporation. Sci. Rep. 8, 4972 (2018).

41. Kiefer, E., Dorr, M., Ibbeken, H. \& Gotze, H. Gravity-based mass balance of an alluvial fan giant: the Arcas Fan, Pampa del Tamarugal, Northern Chile. Rev. Geológica Chile 24, 165-185 (1997).

42. Houston, J. \& Hartley, A. J. The central Andean west-slope rainshadow and its potential contribution to the origin of hyper-aridity in the Atacama Desert. Int. J. Climatol. 23, 1453-1464 (2003).

43. Dunai, T. J., López, G. A. G. \& Juez-Larré, J. Oligocene-Miocene age of aridity in the Atacama Desert revealed by exposure dating of erosion-sensitive landforms. Geology 33, 321-324 (2005).

44. Hartley, A. J., Chong, G., Houston, J. \& Mather, A. 150 million years of climatic stability: evidence from the Atacama Desert, northern Chile. J. Geol. Soc. London. 162, 421-424 (2005).

45. Clarke, J. D. A. Antiquity of aridity in the Chilean Atacama Desert. Geomorphology 73, 101-114 (2006).

46. Houston, J. Evaporation in the Atacama Desert: An empirical study of spatio-temporal variations and their causes. J. Hydrol. 330, 402-412 (2006). 
47. Fuenzalida, H. \& Rutllant, J. Estudio sobre el origen del vapor de agua que precipita en el invierno altiplánico. (1986).

48. Grosjean, M., Geyh, M. A., Messerli, B. \& Schotterer, U. Late-glacial and early Holocene lake sediments, ground-water formation and climate in the Atacama Altiplano $22-24^{\circ}$ S. J. Paleolimnol. 14, 241-252 (1995).

49. Garreaud, R. Multiscale Analysis of the Summertime Precipitation over the Central Andes. Mon. Weather Rev. 127, 901-921 (1999).

50. Houston, J. Groundwater recharge through an alluvial fan in the Atacama Desert, northern Chile: mechanisms, magnitudes and causes. Hydrol. Process. 16, 3019-3035 (2002).

51. Marazuela, M. A., Vázquez-Suñé, E., Ayora, C., García-Gil, A. \& Palma, T. Hydrodynamics of salt flat basins: The Salar de Atacama example. Sci. Total Environ. 651, 668-683 (2019).

52. Cereceda, P., Larrain, H., Osses, P., Farías, M. \& Egaña, I. The spatial and temporal variability of fog and its relation to fog oases in the Atacama Desert, Chile. Atmos. Res. 87, 312-323 (2008).

53. del Río, C. et al. The role of topography in the spatial distribution of the low stratocumulus cloud and fog in the Peruvian coastal desert. in AGU Fall Meeting Abstracts 2018, A31J-2979 (2018).

54. Hasler, K., Jaque, I., Pucheu, A. \& Ortiz, C. Análisis de la información histórica de la operación de la Medida de Mitigación. Estudio de Impacto Ambiental: Modification parcial del Sistema del Sistema de reinyección en los puquios de Llamara, elaborado por Geobiota (2020).

55. Ordoñez, R., Hasler, K., Pucheu, A. \& Ortiz, C. Modelo numérico hidrogeológico acuífero Salar de Llamara. Estudio de Impacto Ambiental, Modificación parcial del Sistema de reinyección en los puquios de Llamara, elaborado por Geobiota (2020).

56. Burow, L. C. et al. Identification of Desulfobacterales as primary hydrogenotrophs in a complex microbial mat community. Geobiology 12, 221-230 (2014).

57. Wierzchos, J., Ascaso, C., Artieda, O. \& Casero, M. C. The Desert Polyextreme Environment and Endolithic Habitats. in Microbial Ecosystems in Central Andes Extreme Environments (ed. Farías, M. E.) 37-49 (Springer, Cham, 2020).

58. Rasuk, M. C. et al. Microbial Characterization of Microbial Ecosystems Associated to Evaporites Domes of Gypsum in Salar de Llamara in Atacama Desert. Microb. Ecol. 68, 483-494 (2014).

59. Garcés, I. et al. Características geoquímicas generales del sistema salino del Salar de Llamara (Chile). Estud. Geológicos 52, 23-35 (1996).

60. López, P. L., Auqué, L. F., Garcés, I. \& Chong, G. Características geoquímicas y pautas de evolución de las salmueras superficiales del Salar de Llamara, Chile. Revista geológica de Chile 26, 89-108 (1999).

61. Zúñiga, L. R., Campos, V., Pinochet, H. \& Prado, B. A limnological reconnaissance of Lake Tebenquiche, Salar de Atacama, Chile. Hydrobiologia 210, 19-24 (1991).

62. Zuñiga, O., Wilson, R., Amat, F. \& Hontoria, F. Distribution and characterization of Chilean populations of the brine shrimp Artemia (Crustacea, Branchiopoda, Anostraca). Int. J. Salt Lake Res. 8, 23-40 
(1999).

63. Ios Rios-Escalante, P. De \& Salgado, I. Artemia (Crustacea, Anostraca) in Chile: a review of basic and applied biology. Lat. Am. J. Aquat. Res. 40, 487-496 (2017).

64. Scott, S. et al. Microbial diversity and trophic components of two high altitude wetlands of the Chilean Altiplano. Gayana 19, 45-56 (2015).

65. Gajardo, G. \& Redón, S. Andean hypersaline lakes in the Atacama Desert, northern Chile: Between lithium exploitation and unique biodiversity conservation. Conserv. Sci. Pract. 1, e94 (2019).

66. Díaz, C. \& Maidana, N. I. Diatomeas de los Salares Atacama y Punta Negra II Región-Chile. Centro de Ecología Aplicada Ltda. \& Minera Escondida Ltda. (2005).

67. Dorador, C., Vila, I., Witzel, K.-P. \& Imhoff, J. F. Cyanobacterial diversity in Salar de Huasco, a high altitude saline wetland in Northern Chile, are highly similar to Antarctic cyanobacteria. FEMS Microbiol. Ecol. 64, 419-432 (2008).

68. Angel, A., Vila, I. \& Herrera, V. Extremophiles: photosynthetic systems in a high-altitude saline basin (Altiplano, Chile). Int. Aquat. Res. 8, 91-108 (2016).

69. Des Marais, D. J. The Biogeochemistry of Hypersaline Microbial Mats. in Advances in Microbial Ecology (ed. Jones, J. G.) (Springer, Boston, MA, 1995). doi:https://doi.org/10.1007/978-1-46847724-5_6

70. Vogel, M. B. et al. The role of biofilms in the sedimentology of actively forming gypsum deposits at Guerrero Negro, Mexico. Astrobiology 9, 875-893 (2009).

71. Vogel, M. B. et al. Biological influences on modern sulfates: Textures and composition of gypsum deposits from Guerrero Negro, Baja California Sur, Mexico. Sediment. Geol. 223, 265-280 (2010).

72. Ali-Bik, M. W., Metwally, H. I. M., Wali, A. M. A. \& Kamel, M. G. Facies and geochemistry of non-marine gypsum, EMISAL, Egypt. Geol. Acta 11, 409-420 (2013).

73. Taher, A. G. Formation and calcification of modern gypsum-dominated stromatolites, EMISAL, Fayium, Egypt. Facies 60, 721-735 (2014).

74. Handford, C. Sedimentology and evaporite genesis in a Holocene continental-sabkha playa basinBristol Dry Lake, California. Sedimentology 29, 239-253 (1982).

75. Gerdes, G., Krumbein, W. E. \& Holtkamp, E. Salinity and Water Activity Related Zonation of Microbial Communities and Potential Stromatolites of the Gavish Sabkha. in Hypersaline Ecosystems. Ecological Studies (Analysis and Synthesis) (eds. Friedman, G. M. \& Krumbein, W. E.) 238-236 (Springer Berlin Heidelberg, 1985). doi:DOI https://doi.org/10.1007/978-3-642-70290-7_14

76. Renfro, A. R. Genesis of Evaporite-Associated Stratiform Metalliferous Deposits; A Sabkha Process. Econ. Geol. 69, 33-45 (1974).

77. Sinclair, A. R. E. \& Walker, B. The Kruger experience: ecology and management of savanna heterogeneity. (Island Press, 2003).

78. Oliver, T., Roy, D. B., Hill, J. K., Brereton, T. \& Thomas, C. D. Heterogeneous landscapes promote population stability. Ecol. Lett. 13, 473-484 (2010). 
79. Oliver, T. H. et al. Biodiversity and Resilience of Ecosystem Functions. Trends Ecol. Evol. 30, 673-684 (2015).

80. Levine, N. M. et al. Ecosystem heterogeneity determines the ecological resilience of the Amazon to climate change. Proc. Natl. Acad. Sci. 113, 793-797 (2016).

81. Timpane-Padgham, B. L., Beechie, T. \& Klinger, T. A systematic review of ecological attributes that confer resilience to climate change in environmental restoration. PLoS One 12, 1-23 (2017).

82. Kotschy, K., Biggs, R., Daw, T., Folke, C. \& West, P. Principle 1-Maintain diversity and redundancy. Princ. Build. Resil. Sustain. Ecosyst. Serv. Soc. Syst. Cambridge Univ. Press. Cambridge, UK 50-79 (2015).

83. Kindvall, O. Habitat Heterogeneity and Survival in a Bush Cricket Metapopulation. Ecology 77, 207214 (1996).

84. Godfree, R. et al. Multiscale topoedaphic heterogeneity increases resilience and resistance of a dominant grassland species to extreme drought and climate change. Glob. Chang. Biol. 17, 943-958 (2011).

85. Dzubakova, K. et al. Environmental heterogeneity promotes spatial resilience of phototrophic biofilms in streambeds. Biol. Lett. 14, 0-3 (2018).

86. Elmqvist, T. et al. Response diversity, ecosystem change, and resilience. Front. Ecol. Environ. 1, 488494 (2003).

87. Patrick, R. Results of research in the Antofagasta ranges of Chile and Bolivia. II. Diatoms (Bacillariophyceae) from the alimentary tract of Phoenicoparrus jamesi. (1961).

88. Mori, A. S., Furukawa, T. \& Sasaki, T. Response diversity determines the resilience of ecosystems to environmental change. Biol. Rev. 88, 349-364 (2013).

89. Kerr, J. T. \& Packer, L. Habitat heterogeneity as a determinant of mammal species richness in highenergy regions. Nature 385, 252-254 (1997).

90. Frenguelli, J. Diatomeas del Río de la Plata. Rev. del Mus. la Plata, Sección Botánica 3, 213-334 (1941).

91. Parra, O., González, M., Dellarossa, V., Rivera, P. \& Orellana, M. Taxonomic manual of phytoplankton of continental waters with special reference to the phytoplankton of Chile: Chlorophyceae. Part III: Cryptophyceae, Dinophyceae, Euglenophyceae. (1982).

92. Parra, O. \& González, M. Taxonomic manual of phytoplankton of continental waters with special reference to the phytoplankton of Chile: Chlorophyceae. Part I: Volvocales, Tetrasporales, Chlorococcales and Ulothricales. (1983).

93. Seeligmann, C. \& Maidana, N. I. Diatomeas (Bacillariophyceae) en ambientes de altura de la provincia de Catamarca (Argentina). Boletín Soc. Argentina Botánica 38, 39-50 (2003).

94. Seeligmann, C., Maidana, N. I. \& Morales, M. Diatoms (Bacillariophyceae) of high altitude wetlands in the Province of Jujuy-Argentina. Boletín Soc. Argentina Botánica 43, 1-17 (2008). 
95. Maidana, N. I. \& Seeligmann, C. Diatomeas (Bacillariophyceae) de ambientes acuáticos de altura de la Provincia de Catamarca, Argentina II. Bolet\{1 'i\}n la Soc. Argentina botánica 41, 1-13 (2006).

96. Álvarez Blanco, I., Cejudo Figueiras, C., Godos, Ignacio, F., Múñoz Torre, R. \& White Lance, S. The diatoms of the salt flats of the Bolivian Altiplano: floristic singularities. Bull. R. Spanish Soc. Nat. Hist. 105, 67-82 (2011).

97. Maidana, N. I. \& Seeligmann, C. T. Diatoms (Bacillariophyceae) in high-altitude wetlands of Catamarca Province (Argentina). III. Bol. LA Soc. ARGENTINA Bot. 50, 447-466 (2015).

98. Woelfl, S., Caputo, L., García-Chicote, J. \& de Los Ríos, P. Manuales para la bioindicación: Zooplancton. Manuales Sociedad Chilena de Limnología 1, (2008).

99. Araya, J. M. \& Zúñiga, L. R. Taxonomic manual of the lacustrine zooplankton of Chile. Limnol. Bull. Univ. Austral Chile 8, 1-69 (1985).

100. Fernández, H. R. \& Domínguez, E. Guide for the determination of South American benthic arthropods (Vol. 1). (2001).

101. Crespo, J. E. \& Baessolo, L. A. Biogeografia y taxonomia del género Artemis (Crustacea, Anostraca) en Chile: una revisión. Hist. Nat. /17-21 (2002).

102. Villalobos, A., Ness, J. E., Gustafsson, C., Minshull, J. \& Govindarajan, S. Gene Designer: a synthetic biology tool for constructing artificial DNA segments. BMC Bioinformatics 7, 285 (2006).

103. Palma, A. T., Schwarz, A. O. \& Fariña, J. M. Experimental Evidence of the Tolerance to Chlorate of the Aquatic Macrophyte Egeria densa in a Ramsar Wetland in Southern Chile. Wetlands 33, 129-140 (2013).

104. Echeverría-Vega, A. et al. Watershed-Induced Limnological and Microbial Status in Two Oligotrophic Andean Lakes Exposed to the Same Climatic Scenario. Front. Microbiol. 9, 357 (2018).

105. Lane, D. J. 16S/23S rRNA sequencing. Nucleic acid Tech. Bact. Syst. 115-175 (1991).

106. Caporaso, J. G. et al. QIIME allows analysis of high-throughput community sequencing data. Nat. Methods 7, 335-336 (2010).

107. Edgar, R. C., Haas, B. J., Clemente, J. C., Quince, C. \& Knight, R. UCHIME improves sensitivity and speed of chimera detection. Bioinformatics 27, 2194-2200 (2011).

108. Clarke, K. R. \& Gorley, R. N. Getting started with PRIMER v7. Prim. Plymouth, Plymouth Mar. Lab. 20 (2015).

\section{Tables}

Due to technical limitations, tables are only available as a download in the Supplemental Files section.

\section{Figures}



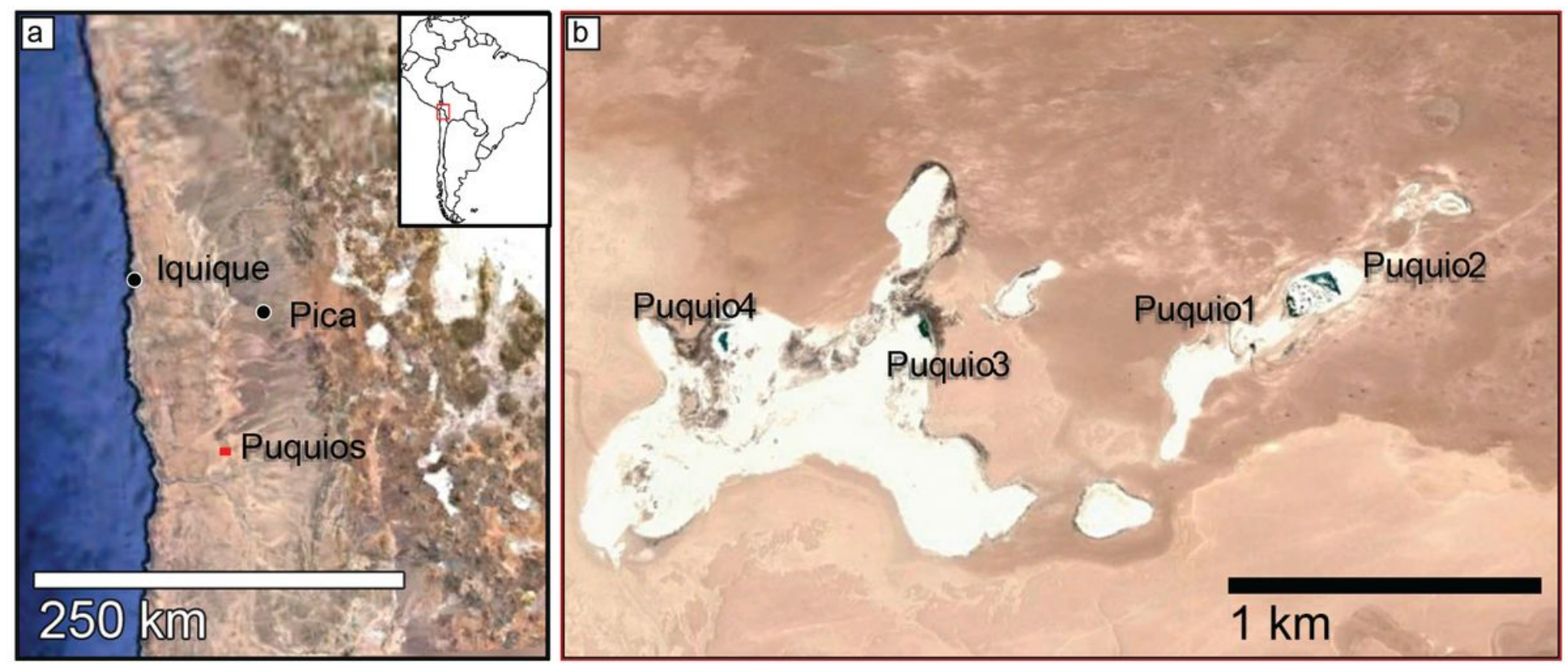

\section{Figure 1}

Location map - (a) regional context and location of the Puquios within northern Chile; (b) enlarged view of the red square in (a) showing the location of the Puquios within the Salar de Llamara. Note: The designations employed and the presentation of the material on this map do not imply the expression of any opinion whatsoever on the part of Research Square concerning the legal status of any country, territory, city or area or of its authorities, or concerning the delimitation of its frontiers or boundaries. This map has been provided by the authors.
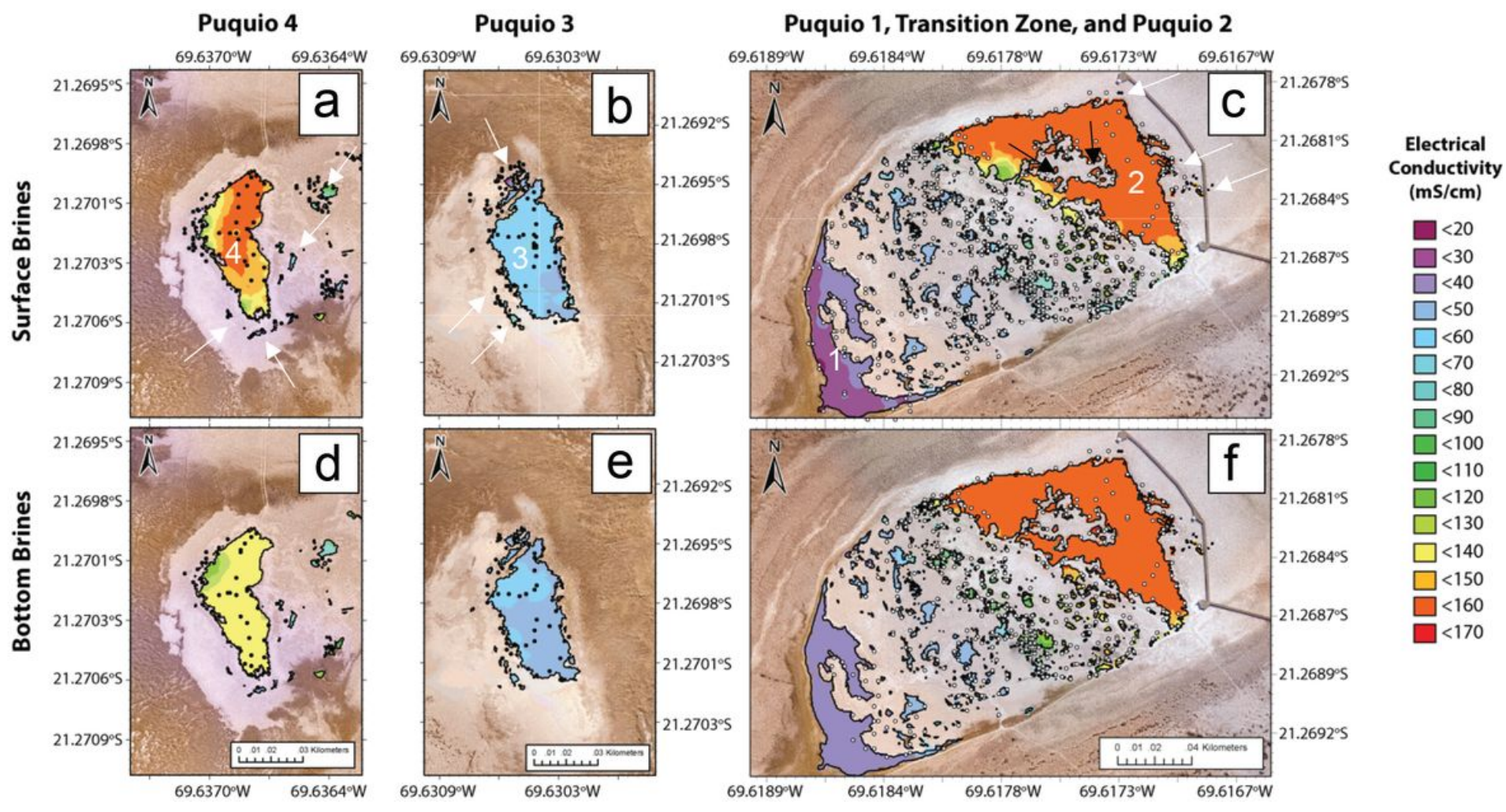

Figure 2 
Contour maps of in situ electrical conductivity $(\mathrm{mS} / \mathrm{cm})$ in the Puquios. Measurement locations are shown as black dots (Puquios 3 and 4), and white dots (Puquios 1, 2, and the Transition Zone). Scale of all maps is 1:1180 km. Surface brine measurements are shown in panels a-c, and bottom brine measurements are shown in panels d-f.
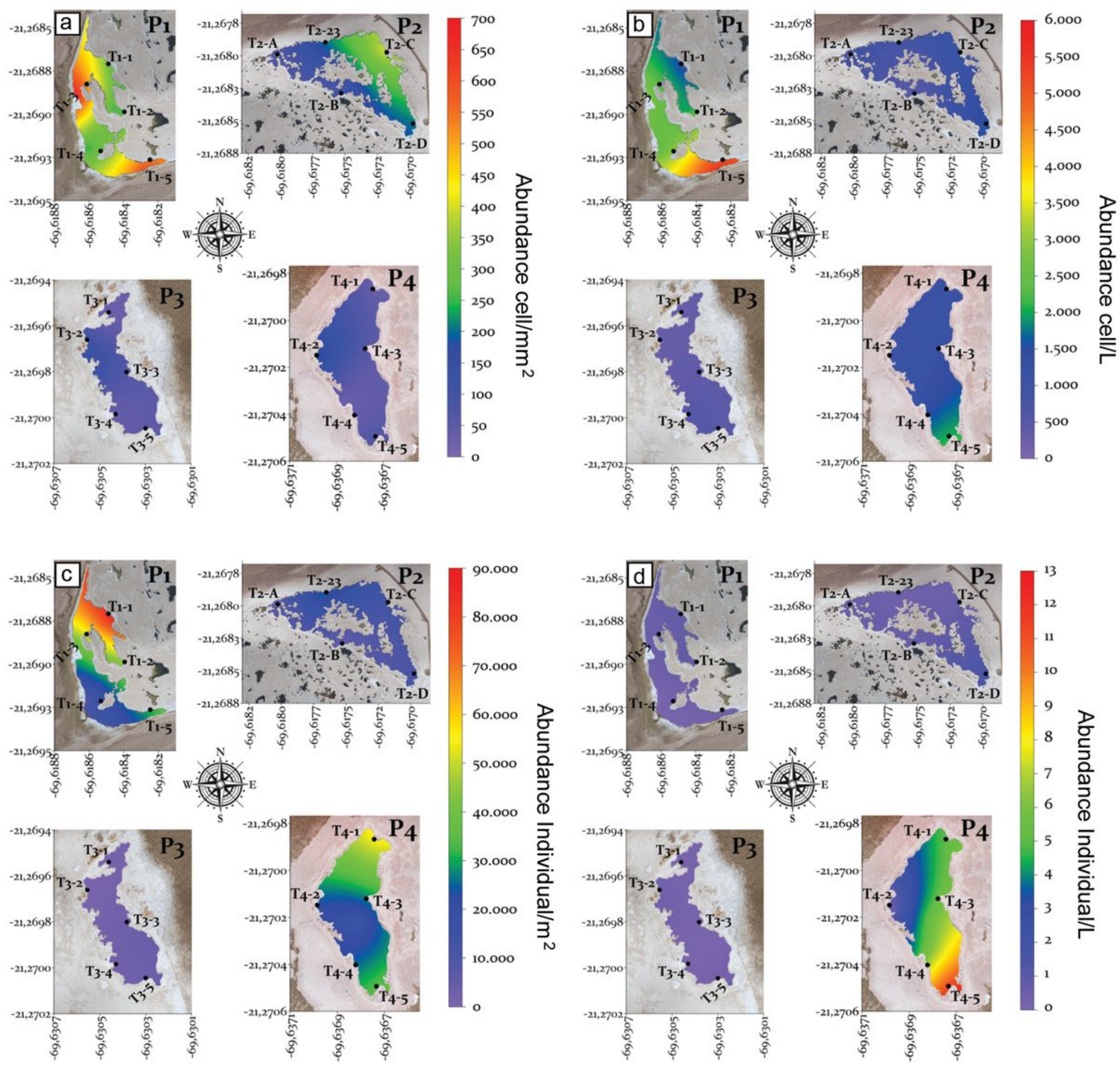

Figure 3

Abundance of the main four assemblages present in the bottom and water column of the 4 Puquios. (a) Phytobenthos, (b) Phytoplankton, (c) Zoobenthos and (d) Zooplankton. 

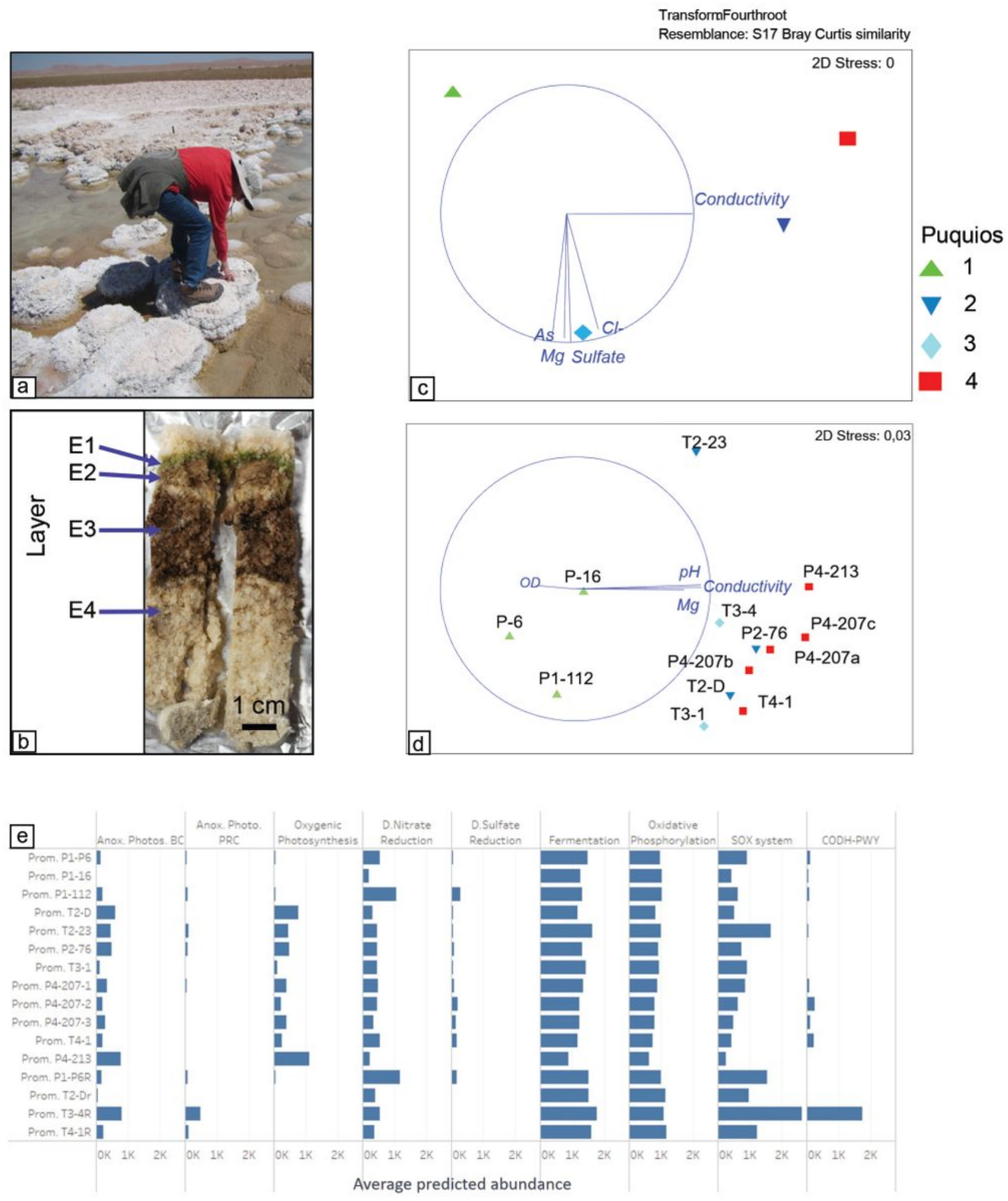

\section{Figure 4}

Microbial community variability in subaerial structures and associated brines. (a) Photograph showing the area sampled from subaerial structures surrounding the Puquios and (b) shows the E1 layer sampled within the mini-core for analysis. (c/d) Nonmetric multidimensional scaling plot of bacterial communities collected from filtered brine water and subaerial gypsum structures showing maximum correlation to local environmental data. (e) Abundance of energy metabolisms predicted by Phylogenetic Investigation 
of Communities by Reconstruction of Unobserved States (PICRUSt) using the 16S rRNA surveys from the green layer (E1) of the gypsum structures and brine samples from the Puquios inside Salar de Llamara (summer 2017).
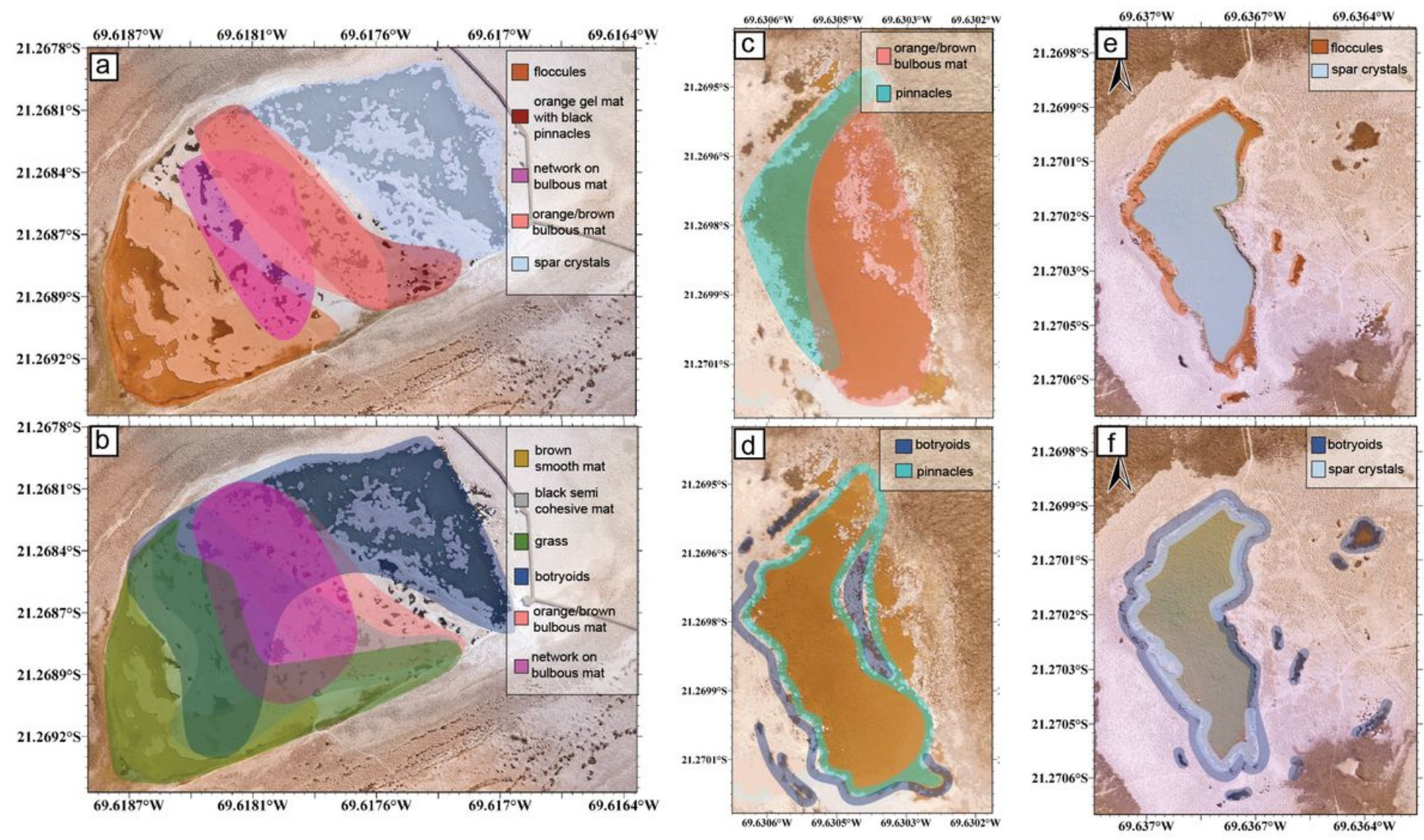

Figure 5

Generalized maps showing geographic trends of principle bottom types (PBT), generated from individual point maps (Supplemental Fig. S3). General location of dominant $a$ ) bottom surfaces and $b$ ) side wall surfaces for Puquios 1 and 2; c) general location of dominant c) bottom surfaces and d) side wall surfaces for Puquio 3; general location of dominant e) bottom surfaces and f) side wall surfaces for Puquio 4. 

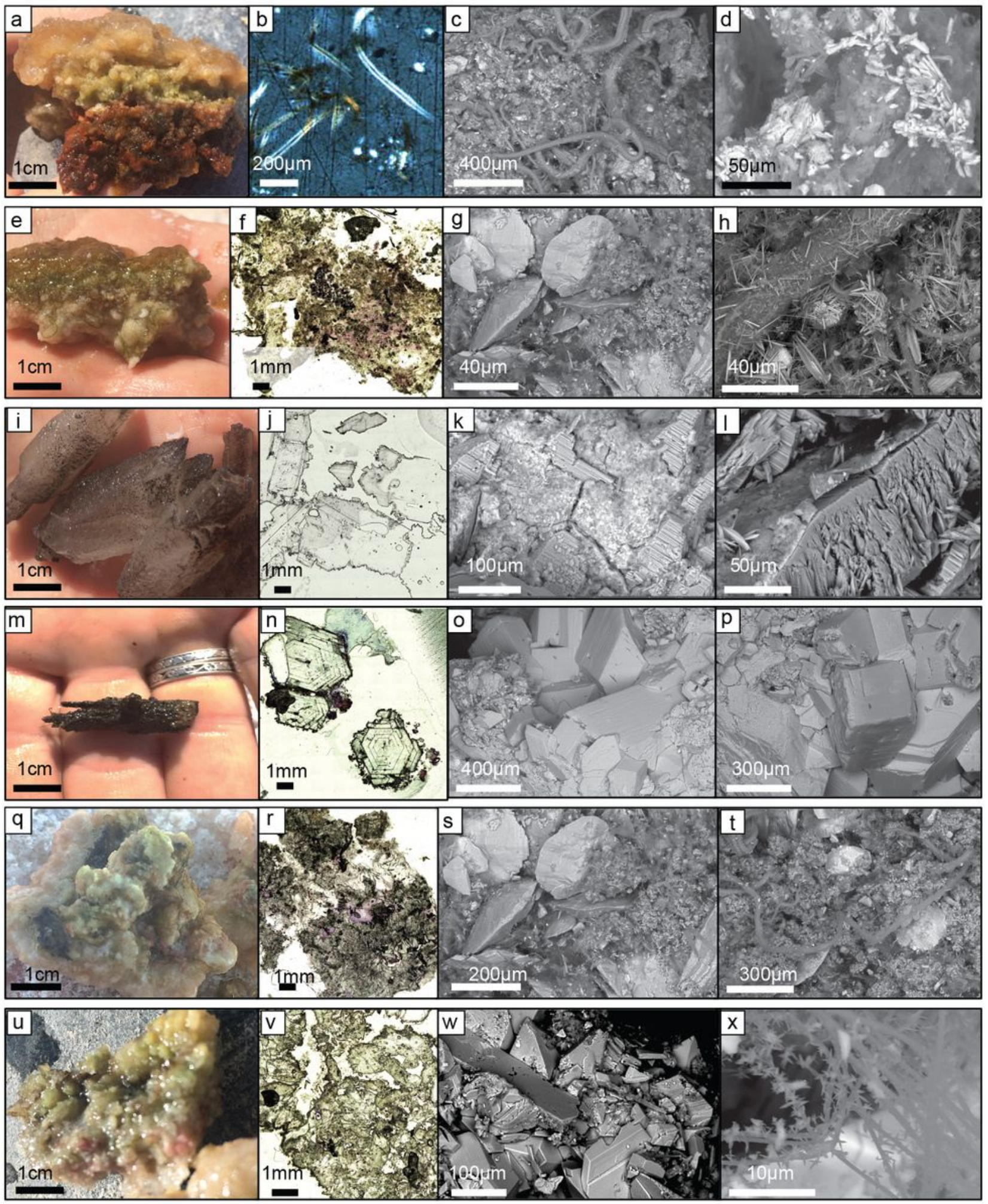

\section{Figure 6}

Microbe-mineral interactions - Orange/brown bulbous mat PBT from Transition Zone between Puquio 1 and 2 (a-d). a) Field photo of hand sample; b) Photomicrograph of "wet" thin section under crosspolarized light of $\mathrm{Mg}$-silicates forming along cyanobacterial sheaths that exhibit sweeping extinction; $\mathrm{C}$, d) SEM photomicrographs showing microcrystalline gypsum crystals in an EPS matrix with cyanobacterial filaments. Orange gel mat PBT from Transition Zone between Puquio 1 and 2 (e-h). e) 
Field photo of the collected hand sample showing orange gel, green and purple microbial layers, and granular minerals. f) Photomicrograph of wet thin section stained with crystal violet to highlights gram positive bacteria; $g, h$ ) SEM photomicrographs of critically dried samples showing gypsum crystals in an EPS matrix (g) and acicular crystals coating a cyanobacterial filament $(\mathrm{h})$. Spar crystals PBT sampled from a small lagoon near Puquio 2 (i-l). i) Field photo of hand sample; j) Photomicrograph of "wet" thin section showing coarse gypsum crystals, often with jagged outer surfaces with dark coatings; $k, l)$ SEM photomicrographs showing large flat crystal faces coated with a thin crust, rich in manganese (as shown by EDS). Spar crystals PBT sampled from a small lagoon near Puquio $2(m-p)$. m) Field photo of hand sample; $n$ ) Photomicrograph of "wet" thin section showing microcrystalline gypsum, a strip of lenticular sparry gypsum and patch of blocky to prismatic gypsum; purple in voids indicates bacterial presence; 0 , p) SEM photomicrographs show large blocky, flat crystal faces, coated with granular aggregates rich in manganese, as shown by EDS. Pinnacles PBT sampled along the northern margin of Puquio $3(q-t) . q)$ Field photo of hand sample; r) Photomicrograph of "wet" thin section showing coarse gypsum crystals, often with jagged outer surfaces with dark coatings; s) SEM photomicrographs showing lenticular gypsum embedded in a fine-grained gypsum mesh; $t$ ) and filamentous cyanobacteria with tiny gypsum crystals embedded in or coating sheaths. Botryoids PBT sampled from within Puquio 4 (u-x). u) Field photo of hand sample; v) Photomicrograph of "wet" thin section showing crystalline matrix of prismatic

gypsum; edges are coated with a fine microcrystalline crust; $w$ ) SEM photomicrographs showing blocky crystals with planar faces; $x$ ) and fine cyanobacterial filaments with stellate crystals adhering to the sheaths.

\section{Supplementary Files}

This is a list of supplementary files associated with this preprint. Click to download.

- ReidTable1.xlsx

- ReidTable2.xlsx

- ReidTable3.xIsx

- ReidSupplementalFigureS1.jpg

- ReidSupplementalFigureS2.jpg

- ReidSupplementalFigureS3.jpg

- ReidSupplementalFigureS4.jpg

- ReidSupplementalFigureS5.jpg

- ReidSupplementalTableS1.xlsx

- ReidSupplementalTableS2.xlsx

- ReidSupplementaryMaterial.docx 